\title{
The Supreme Court, Maritime Law and the Offshore
}

\author{
WYLIE SPICER, Q.C.
}

This article provides an analysis of Canadian maritime law and its impact on offshore operations in the context of a recent decision by the Supreme Court of Canada in Bow Valley Husky (Bermuda) Ltd. v. Saint John Shipbuilding Ltd. The author reviews the decision and discusses how it will impact some key aspects of maritime contracts.
Le présent article fournit une analyse du droit maritime canadien et de son impact sur les opérations en mer dans le contexte de la décision récente de la Cour suprème du Canada dans Bow Valley Husky (Bermuda) Ltd. c. Saint John Shipbuilding Lid. L'auteur examine la décision et parle de ses répercussions sur certains aspects importants des contrats maritimes.

\section{TABLE OF CONTENTS}

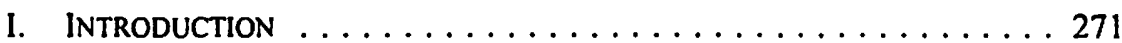

A. THE BOW VALLEY DECISION .............. 271

B. What FollowS FROM THE DECISION ........... 273

II. A Generic Definition of CANADIAN MARITIME LAW . . . . . 273

III. MARITIME CONTRACTS - SOME CONTRACTUAL ISSUES ..... 275

A. THE UNDERTAKING OF SEAWORTHINESS . . . . . . . . 275

B. THE INABILITY OF A TIME CHARTERER to ReCOVER

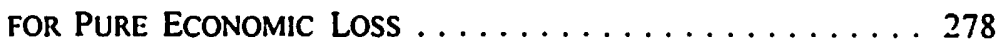

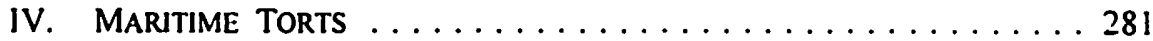

A. Personal InJURIes $\ldots \ldots \ldots \ldots \ldots \ldots \ldots \ldots \ldots \ldots 28$

B. Salvage Services $\ldots \ldots \ldots \ldots \ldots \ldots \ldots \ldots \ldots \ldots \ldots \ldots$

V. Choice of Law Issues $\ldots \ldots \ldots \ldots \ldots \ldots \ldots \ldots \ldots 283$

\section{INTRODUCTION}

The decision of the Supreme Court of Canada in Bow Valley Husky (Bermuda) Lid. v. Saint John Shipbuilding Ltd.' confirms that many aspects of oil and gas operations in the Canadian offshore are governed by Canadian maritime law. Additionally, the decision attempts to clarify some of the issues related to the recovery of pure economic loss and the scope of a manufacturer's duty to warn. This article considers the implications of applying Canadian maritime law to the Canadian offshore using the Bow Valley decision as a backdrop.

\section{A. The Bow Valley Decision}

The Bow Valley case arose out of the construction by Bow Valley Husky (Bermuda) Limited ("BVHB") of a semi-submersible oil rig at a shipyard operated by Saint John Shipbuilding Limited (the "Yard"). Raychem Canada Ltd. ("Raychem") supplied a heat tracing system to the Yard for installation on the rig. This system was composed of an electrical wire wrapped around piping to eliminate freezing of liquids in the pipe. The 
electrical wire was covered with a rubber wrap to keep moisture away from the wire. This wrap was flammable.

The rig was chartered to Husky Oil Operations Limited ("HOOL") and Bow Valley Industries Limited ("BVI"). Depending on the location of the rig, either the HOOL charter or the BVI charter would be in effect. The charters had identical terms. The rig was crewed and operated by BVHB, with HOOL and BVI having the right to direct where the rig was to drill.

While drilling in offshore Newfoundland, a fire occurred on the rig, which was precipitated by the wire and the wrap. At trial, and in the Newfoundland Court of Appeal, BVHB was found 60 percent contributorily negligent and the remaining 40 percent was divided equally between the Yard and Raychem because of their failure to warn BVHB that the wrap would burn. ${ }^{2}$

The charterers, HOOL and BVI, lost the service of the rig for many months and claimed against the Yard and Raychem to recover their economic losses. ${ }^{3}$ One of the provisions of the charter required $\mathrm{HOOL}$ and BVI to continue paying the dayrate, notwithstanding that the rig was out of service. The provision permitted HOOL and BVI to discontinue such payments after the expiration of a period of time. However, $\mathrm{HOOL}$ and BVI continued to make payments past this period.

The claims of HOOL and BVI for pure economic loss were dismissed by the Supreme Court of Canada, characterizing the nature of their claims as "contractual relational economic loss." In other words, any claim of the charterers was based on the fact that they had a contract with BVHB and that HOOL and BVI suffered losses as a consequence of damage to the property of BVHB. Specifically, due to the terms of the charter, HOOL and BVI were required to continue paying the dayrate, notwithstanding that the rig was out of service.

The Supreme Court of Canada characterized the case as involving "tortious liability arising in a maritime context." Raychem and the Yard had argued that since the case was governed by Canadian maritime law, rather than provincial legislation, they could take the benefit of the common law contributory negligence bar which, if applicable, would disallow the claims of the plaintiffs who had been found to be contributorily negligent. The Supreme Court of Canada determined that changing this common law rule was "clearly necessary to keep the law in step with the 'dynamic and evolving

In the Supreme Court of Canada, lacobucci J., for the majority, found that the Yard was contractually protected from any duty to wam BVHB (ibid. at 428). McLachlin J. and La Forest J. dissented on this point and would not have found the Yard to be protected by the contract (ibid. at 399).

1 BVHB advanced a claim for physical damage to the rig and were ultimately found to be able to recover $\mathbf{4 0}$ percent of that claim. BVHB had no claim for economic loss.

+ Supra note I at 406.

s $\quad$ Ibid. at 418 . 
fabric of our society' and the ramifications of the change are not incapable of assessment."'

It was necessary for the court to deal with the contributory negligence bar because, in a series of recent decisions, the court had consistently stated that Canadian maritime law is federal, whether statute or common law, and does not include the law of any province. ${ }^{7}$ Accordingly, in this case, the contributory negligence legislation of the Province of Newfoundland was not available to the court.

\section{B. What FOLLOWS FROM THE DECISION}

Reduced to its essentials, the Bow Valley decision confirms the following:

(1) Most contract and tort claims arising offshore will be governed by Canadian maritime law.

(2) It will be very difficult for charterers (and others) to recover against third parties in respect of claims which are purely economic in nature and not founded upon a direct claim for physical damage.

\section{A Generic Definition of Canadian MaRitime Law}

Some things which happen at sea are obviously maritime. Some of the more obvious examples include: collisions between ships, salvaging vessels in trouble and carrying containers by ship from one port to another. In order to fully appreciate the broadreaching scope of Canadian maritime law, it is useful to review its elements as defined and refined by the Supreme Court of Canada. Maritime "matters" are those:

[T] hat the subject-matter under consideration in any case [be] so integrally connected to maritime matters as to be legitimate Canadian maritime law within federal legislative competence."

This general requirement is applicable to both tort and contract matters. In the Bow Valley case, McLachlin J. commented on this aspect of the case:

The rig was not only a drifting [drilling?] platform, but a navigable vessel. As Cameron J.A. [of the Newfoundland Court of Appeal] put it at pp. 133-34, the rig "is capable of self-propulsion; even when drilling, is vulnerable to the perils of the sea; is not attached permanently to the ocean floor and, can travel world wide to drill for oil." Alternatively, even if the rig is not a navigable vessel, the tort claim

$6 \quad$ Ibid. at $\mathbf{4 2 1}$.

1 ITO - International Terminal Operators Limited v. Miida Electronics Inc., [1986] 1 S.C.R. 752 [hereinafter ITO]; Whitbread v. Walley, [1990] 3 S.C.R. 1273; and Q.N.S. Paper Co. v. Chartuell Shipping Limited, [1989] 2 S.C.R. 683. In Bow Valley, the court was also faced with a series of admiralty decisions which had applied the common law contributory negligence bar (referred to at $\mathbf{4 2 0}$ of the decision) which, since provincial legislation did not form part of Federal maritime law, would have been applicable had the court taken a conservative route and not amended the common law.

ITO, ibid. at 774. 
arising from the fire would still be a maritime matter since the main purpose of the Bow Drill III was activity in navigable waters.'

The Supreme Court of Canada has also commented that this requirement of integral connection to maritime matters must be assessed in the modern context. In Monk Corp. v. Island Fertilizers Limited, ${ }^{10}$ lacobucci J. commented:

The terms "maritime" and "admiralty" should be interpreted within the modern context of commerce and shipping and should not be static or frozen. Such terms should rather be capable of adjusting to evolving circumstances unencumbered by rigid doctrinal categorization and historical straightjackets."

It is important to understand that the court looks at maritime matters in this context. There are some activities which would not obviously appear to be maritime, but which have been so characterized by the Supreme Court of Canada. The theft of calculators from a storage shed in Montreal following discharge from a ship would not necessarily seem to be maritime. ${ }^{12}$ A loss onboard a vessel caused by a manufacturing defect in a product made onshore and used in many industries besides shipping, might not appear an obvious candidate for maritime status. ${ }^{13}$ But the Supreme Court of Canada has found both these situations to be maritime.

Maritime contracts will also be governed by Canadian maritime law. A contract to build a ship is maritime. ${ }^{14}$ Certainly, a contract to build an offshore drilling rig would be similarly characterized. Drilling contracts used in the offshore are maritime and would be subject to the application of the principles of Canadian maritime law. ${ }^{\text {is }}$

Maritime law is also uniform from coast to coast. ${ }^{16}$ Statutory laws of the provinces do not form part of maritime law. ${ }^{17}$ For instance, to the extent that the provincial legislatures have addressed this issue, most provincial statutes dealing with the registration of chattel mortgages exclude ships registered under the Canada Shipping Act. ${ }^{18}$ Provincial statutes which provide for the calculation of interest, whether pre-

Supra note 1 at 418.

(1991), 123 N.R. 1.

lbid. at 25.

ITO, supra note 7 at 775 .

Bow Valley, supra note 1 at 417.

R. v. Canadian Vickers Limited, [1980] I F.C. 366 (C.A.); Benson Brothers Shipbuilding Co. (1960) Lid. v. Mark Fishing Co. Limited (1979), 89 D.L.R. (3d) 527 (F.C.A.).

is The only decision that could have been said to be contrary to this position is the decision of Dube J. of the Federal Court in Dome Petroleum Lid. v. N. Bunker Hunt, [1978] 1 F.C. 11 (T.D.) [hereinafter Dome]. That case involved litigation concerning breach of a drilling contract for drilling in the Beaufort Sea using drill ships. Dube J. found that the matter was not maritime. The drill ship was not navigating as it performed its main function of drilling. In Bow Valley, the court found that the main purpose of the Bow Drill III "was activity in navigable waters" (supra note 1 at 418). This characterization of the main purpose of a drilling rig would certainly require that the Dome case would now be differently decided. 
judgment or otherwise, are not applicable to litigation governed by maritime law in which interest is calculated in accordance with the relevant case law. ${ }^{19}$

\section{Maritime Contracts - Some Contractual IsSues}

Drilling contracts for the offshore are to be characterized according to the principles of maritime law. Most drilling contracts involve the leasing of a drill rig from a drilling company to an oil company. For the most part, the crewing of the rig is the responsibility of the rig owner. The persons onboard the rig will carry out both traditional maritime functions (such as master, chief engineer) and non-maritime functions (the drilling crew). In addition, the oil company client will, from time to time, have a number of people onboard the rig carrying out various functions (wire line, mud engineering, cementers and directional drilling personnel).

A drilling contract is usually for a specified period of time, often being the amount of time anticipated to complete the exploration program. In maritime parlance, this would qualify as a time charter by which a ship is leased to a charterer, but the responsibility for operating the ship remains with the shipowner. ${ }^{20}$

\section{A. THE UNDERTAKING OF SEAWORTHINESS}

There is an implied undertaking in a time charter that the ship is seaworthy. Whether or not the charterer can treat the charter as discharged by reason of a breach of this undertaking depends on the extent of the breach. There are several important aspects to this undertaking which are relevant in drafting drilling contracts:

(1) The required seaworthiness is relative to the nature of the ship.

(2) The ship must be fit in the sense that it is fit to deal with the ordinary perils to which it is likely to be subjected.

(3) The standard of seaworthiness may be affected with improved knowledge of shipbuilding.

Winslow Marine Ry \& Shipbuilding Co. v. The Ship "Pacifico," [1924] Ex. C.R. 90, affd [1924]

Ex. C.R. 163. The principle was explained by Addy J. in Bell Telephone Company of Canada v.

The Ship Mar-Tirenno, [1974] I F.C. 294 at 311:

The Admiralty Courts, in the exercise of their jurisdiction, proceeded upon difference principles from that on which the common law authorities were founded; the principle in this instance being a civil law one, to the effect that, when payment is not made, interest is due to the obligee ex mora of the obligor.... [T] he principle is based on the right of the plaintiff to be fully compensated, including interest.

This principle applies regardless of whether the claim is in contract or tort (The Northumbria (1869), L.R. 3 A. \& E. 6).

20 For a good discussion of the nature of time chanterers, see Wilford, et al., Time Charlerers, $3 \mathrm{~d}$ ed. (London: Lloyds of London Press Lid., 1989), and Scrutton on Charter Parties, 20th ed. (London: Sweet \& Maxwell, 1996). 
(4) The competence of the Master and crew is a consideration in evaluating seaworthiness.

(5) A shipowner will be liable for loss caused by breach of the seaworthiness obligation.

(6) This obligation may be avoided by suitable contractual wording.

It is important to have a sense of the maritime cases dealing with these aspects so they can be considered in interpreting the "seaworthiness" provisions of drilling contracts. The usual sort of representation in a drilling contract may be in the following terms:

(1) Contractor's equipment will be in good working order.

(2) Whereas contractor is engaged in the business of drilling, testing and completing, working over and deepening of wells; represents that it has adequate resources and equipment in good working order and fully trained personnel capable of efficiently operating such equipment.

\section{SEAWORTHINESS Relative to NATURE OF tHE ShIP}

In Burgess v. Wickham, ${ }^{21}$ the issue was whether a vessel which was built for navigating internal waters, not general ocean navigation, was seaworthy. Although everything had been done that could have been done to render a vessel of her construction as strong as she could be made to encounter the perils of the voyage, the vessel became a total loss. Cockburn C.J. concluded that "[w] here it was known that the vessel was not properly fitted for an ocean voyage, it could not be said that it was unseaworthy."22

In a context of the offshore, this aspect of the doctrine of seaworthiness is marginally relevant in as much as great care is taken to ensure that the particular type of rig is suitable for the environment in question. It should be noted in passing, however, that the acquisition of certificates of seaworthiness and other required certificates does not necessarily mean that a vessel is seaworthy. ${ }^{23}$

\section{Fit for the ORDINARY PERILS to BE EXPECTED}

This aspect has been succinctly stated by Scrutton as follows:

The undertaking of seaworthiness requires not merely that the shipowner will do and has done his best to make the ship fit, but that the ship really is fit in all respects to carry her cargo safely to its

(1863), 3 B. \& S. 669.

Ibid. at 682.

Charles Goodjellow Lumber Sales Limiled v. Verreault, [1971] S.C.R. 522. 
destination, having regard to the ordinary perils to which such a cargo would be exposed on such a voyage. $^{24}$

\section{SEAWORTHINESS AFFECTED WITH IMPROVED KNOWLEDGE OF SHIPBUILDING}

This is a state-of-the-art defence. Seaworthiness does not require perfection, but merely reasonable compliance with existing standards. In Western Canada Steamship Company Ltd. v. Canadian Commercial Corporation, ${ }^{25}$ the Supreme Court of Canada concluded that no breach of the warranty of seaworthiness could be relied upon where a defect could not reasonably have been ascertained prior to a loss. Therefore, it will not be a breach of the obligation of seaworthiness if a rig is lost due to a cause which, in hindsight, experts may opine was a fault in design, although not generally known at the time of the loss.

\section{COMPETENCE OF MASTER AND CREW}

In discussing this aspect of the seaworthiness obligation, one must initially focus on the meaning of "crew." In the maritime context, a seaman is defined in the Canada Shipping $A c t$ as including "[e]very person, except masters, pilots and apprentices duly indentured and registered, employed or engaged in any capacity on board any ship." 26

This definition has been considered to include surgeons, ${ }^{27}$ carpenters $^{28}$ and stewards in charge of the ship's bar. ${ }^{29}$ Certainly the persons carrying out the drilling function onboard a rig would be considered to be crew for the purposes of the seaworthiness obligation, as would, for instance, the ballast control operator.

Insufficiency in the required number of crew members has also been found to constitute unseaworthiness. In The Heinz Horn ${ }^{30}$ the Fifth Circuit Court in the United States found a vessel unseaworthy due to the following crew insufficiencies:

(1) the captain was ill, did not supervise loading and left the vessel before the end of the voyage;

(2) at no time during the voyage did the vessel have the normal complement of officers;

(3) the officers had no experience with the cargo in question; and

(4) once the captain left the ship, the vessel had only two mates.

Supra note 20 at 97.

[1960] S.C.R. 632.

Supra note 18, s. 2.

The Wharion (1761), 3 Hag. Adm. 148.

The Bulmer (1823), 1 Hag. Adm. 163.

Thompson v. H. \& W. Nelson. Lid. (1913), 2 K.B. 523.

1 Lloyds Rep. 191 (5th Cir. 1970). 
Although this is an extreme example, the requirement of sufficiency and competence of crew must be noted.

\section{LIABILITY FOR LOSS CAUSED BY BREACH}

Generally, a shipowner whose ship is unseaworthy will be liable in damages for injury to cargo caused directly by the unseaworthiness, but not for injury caused to other portions of the cargo caused by a peril of the sea. ${ }^{31}$ The obligation to prove the connection between the unseaworthiness and the loss is on the party claiming the loss.

\section{AVOIDING the Obligation by SUITABle WORDING}

Drilling contracts tend to contain absolute obligations of seaworthiness at the time of delivery of the rig to the oil company. The issue that usually needs to be addressed is the extent of this obligation through the term of the drilling contract. If this is not addressed, it may be inferred that the absolute obligation survives throughout the term of the contract.

In traditional charterparties, one frequently encounters clauses which reduce the absolute obligation to one of "due diligence" during the term of the contract. Due diligence has been described as "[n]ot merely a praiseworthy or sincere, though unsuccessful, effort, but such an intelligent and efficient attempt as shall make it so [seaworthy], as far as diligence can secure it." ${ }^{32}$

\section{B. The Inability of a Time Charterer to RECOVER FOR PURE ECONOMIC LOSS}

In Candlewood Navigation Corporation v. Mitsui O.S.K. Lines Ltd., the Privy Council articulated the well-established rule of maritime law concerning the inability of a time charterer to recover for loss due to damage by a third party to the chartered vessel:

This issue is one of fundamental importance in maritime law and in the law of negligence generally. There is a long line of authority in the United Kingdom for the proposition that a time charterer is not entitled to recover for pecuniary loss caused by damage by a third party to the chartered vessel. The reason is that a time charterer has no proprietary or possessory right in the chartered vessel; his only right in relation to the vessel is contractual."

The Privy Council went on to state the rationale for the rule in maritime cases:

The policy of imposing such a limit is consistent with the policy of limiting the liability of ships and aircraft in maritime and aviation law by statute and by international agreement. The common law limitation which has been generally accepted is that stated by Scrutton L.J. in Elliot Steam Tug Co. 
Ltd. v. Shipping Controller, [1922] 1 K.B. 127, 139-140, which has been already mentioned. Not only has that rule been generally accepted in many countries including the United Kingdom, Canada, the United States of America and until now Australia, but it has the merit of drawing a definite and readily ascertainable line. It should enable legal practitioners to advise their clients as to their rights with reasonable certainty, and their Lordships are not aware of any widespread dissatisfaction with the rule.

The rule prohibiting recovery by a time charterer for economic loss is long-standing and is well understood in maritime law. It has been applied in Canada, the United States, England and Australia. ${ }^{35}$

In CNR v. Norsk Pacific Steamship Company, ${ }^{36}$ La Forest J. noted that the reason for this exclusionary rule is a refusal of the courts to protect negligent interference with contracts of this type. ${ }^{37}$ In referring to the time charter in the leading American case of Robins Drydock \& Repair Company v. Flint, ${ }^{38}$ La Forest J. noted in Norsk that the determining factor was the character of the contract. ${ }^{39} \mathrm{~A}$ time charterer relationship does not place the charterer in a position of sufficient proximity and in such cases, as noted by La Forest J., recovery is "regularly denied." 40 Candlewood was a striking case because the time charterer was in fact the owner of the vessel.

In Bow Valley, the Supreme Court of Canada did not refer to the maritime cases, although it was arguable that the facts of the case placed the charterers, HOOL and BVI, exactly in the position of the unsuccessful plaintiffs in the time charter cases. Instead, the court chose to address the question by asking whether or not Raychem owed a duty to warn HOOL and BVI. While the court's resolution of this issue is not relevant to the scope of this article, it is clear that the court's analysis of the issue is problematic. $^{41}$

Ibid. at 25.

is Warner Quinlan Asphalt Company v. R., [1924] S.C.R. 236 at 244; Deep Sea Takers Limired and Shell Oil Company v. The Ship "Tricape," [1956] Ex. C.R. 221 at 224, rev'd [1958] S.C.R. 585; Bethlehem Steel Corp. v. St. Lawrence Seaway Authority (1977), 79 D.L.R. (3d) 522 at 525 (F.C.T.D); State of Louisiana v. M/V "TESTBANK", 752 F. 2 d 1019 (5th Cir. 1985); Candlewood, supra note 33 at 18; and Robins Drydock \& Repair Company v. Flint, 275 U.S. 303 (1927) [hereinafter Robins Drydock]. [1992] 1 S.C.R. 1021 [hereinafter Norsk].

Jbid. at 1075.

Robins Drydock, supra note 35.

Supra note 36 at 1075.

Ibid. at 1090.

McLachlin J. analyzed the duty to warn in the context of relational loss which is based on a proximity analysis. McLachlin J. concluded that since Raychem knew of the existence of the plaintiffs and others like them, they should have known that they stood to lose money if the drilling rig was out of service (supra note 1 at 411 ). The difficulty with this analysis is that HOOL and BVI were not "users" of the rig in any sense. They were not responsible for the safety of the rig and were obviously not owed a direct duty to wam or there would have been no necessity for an analysis based on relational economic loss. McLachlin J. found that there was a prima facie duty to wam HOOL and BVI but then negatived that duty because of the problem of indeterminacy (i.e., there would be too many plaintiffs). Unfortunately, this analysis enables the plaintiff, who is not a user of the product in question, to argue that simply because the defendant 
What is important to note is that maritime law generally denies recovery for pure economic loss to a time charterer. Some drilling contracts, notably those that form part of a financing package rather than an arm's length transaction between an unrelated drilling company and oil company, contain provisions that require the oil company to continue making payments, notwithstanding that the rig is out of service. This obviously guarantees payment to the mortgagee.

In the financing type drilling contracts, it may be prudent for counsel to consider, following a loss to the oil rig, whether the oil company should continue to make payments, notwithstanding their apparent obligation to do so in the contract. It may be arguable, for instance, that the loss to the rig has been caused by a breach of the obligation of seaworthiness, thus relieving the oil company from making further payments. The reason for considering such an approach is that the drilling company would then be denied the benefit of the dayrate payments as a consequence of the damage to the rig. It could then, in turn, claim as part of its loss the dayrates that it did not receive during the down time. Economic loss, consequent upon physical loss, is recoverable. The quantum of the economic loss would not be the same as the dayrate, since the rig would have no operating costs incurred during the down time. However, at least some of the economic loss incurred by the venture might be recoverable by this method.

In Bow Valley, McLachlin J. noted that the parties to the drilling contract had contractually allocated the consequences of downtime of the rig. The court also noted that the parties had provided in the drilling contracts the manner in which liability, as between themselves, would be allocated and had also made provision for third party claims arising out of the rig operation. ${ }^{42}$ In the Newfoundland Court of Appeal, Cameron J.A. specifically referred to this risk allocation as a reason for denying recovery to the economic loss claimants:

[T]his case is an excellent example of the circumstances under which the exclusionary rule can operate with certainty and where the parties were in a position to take steps to protect themselves. Here, three sophisticated contracting parties made arrangements that were to their mutual benefit in another context. This is not a case where the relative positions of the contracting parties made one of them powerless to effectively bargain. BVI and HOOL assumed the risk of day rates for repair time without reference to cause of the repairs. On one level, it could be said that their losses arises [sic] from the contracts and they cannot complain if they did not take adequate steps to protect themselves against this type of loss; the parties having determined the matter under contract, tort law should not interfere."

knew who they were, they should be able to recover if they can overcome the indeterminacy problem. This "known plaintiff" test was specifically rejected by the Supreme Court of Canada in Norsk, supra note 36. 


\section{MARITIME TORTS}

The Bow Valley case was a product liability tort claim premised on the duty to warn. McLachlin J. rejected the suggestion made by the plaintiffs that maritime law was not applicable because the product that caused the fire had no relationship to the navigation of the rig:

The plaintiffs submit that maritime law should not apply because the Thermaclad had no relationship to the rig's navigational equipment and because the claims are advanced in tort and contract, rather than navigation and shipping. However, the legal nature of a claim is not the decisive factor in the determination of whether the principals of maritime law apply."

McLachlin J. went on to conclude that "[t]he products liability issues in this case are clearly dominated by marine considerations." 45

This analysis is consistent with the American cases which have consistently taken maritime jurisdiction over product liability claims involving ships. For instance, in Jig III Corporation v. Puritan Marine, the Fifth Circuit Court stated:

When an ocean-going shrimp boat sinks in 15 fathoms of water in the Gulf of Mexico and the sinking is allegedly tortious, there is maritime locality plus a significant relationship to traditional maritime activity, and tort, if recognized by the law, is maritime in nature. This would be true even though the conduct complained of may have been negligent construction or defective design and may have occurred ashore."

Other American cases where maritime jurisdiction has been confirmed include those involving the death of a seaman caused by exposure to asbestos. ${ }^{47}$

The responsibility for legislating in the area of maritime torts rests solely with Parliament. In Whitbread v. Walley, La Forest J., speaking for the court, stated that "[t]ortious liability which arises in a maritime context is governed by a body of maritime law within the exclusive legislative jurisdiction of Parliament." 48

The following section will consider the type of torts that may occur to, or on, an oil rig which would be considered within maritime jurisdiction and the consequences of this conclusion.

Supra note 1 at 417.

Ibid. at 418.

[1976] A.M.C. 118 at 121 [emphasis added].

Swogger v. Waterman S.S., [1987] A.M.C. 2679, 151 A.D. 2 d 100. See also E. Silva, "Admiralty Law and Offshore Drilling Units; An American Overview" (1986) Offshore Petroleum Installation's Law and Financing 85; and M.B. Summerskill, Oil Rigs: Law and Insurance (London: Stevens, 1979).

Supra note 7 at 1289. 


\section{A. Personal inJuries}

Maritime law provides that injuries caused to a person as a result of damage or injury caused by the ship will be accorded the status of a maritime lien. ${ }^{49}$ Personal injury sustained by a person onboard a ship as a result of negligence in the operation of the ship, although giving rise to a claim in rem, would not give the plaintiff maritime lien status. ${ }^{\text {so }}$

The claim of a diver injured by the paddle wheel of a steamer would be accorded maritime lien status, whereas a claim for personal injury sustained as a result of falling down into the hold of a vessel would not give maritime lien status. ${ }^{\text {st }}$ For the plaintiff, whose personal injury claim can be construed as caused by the ship, the maritime lien status of the claim is significant. In essence, it means that the plaintiff can commence an action against the rig and have it arrested, regardless of whether the owner of the rig would be liable for the accident. For instance, if a member of the drilling crew were injured due to the negligence of an oil company client representative onboard the rig, such that the injury could be said to have been caused by the rig, then even though the owner of the rig would not be liable in personam, the plaintiff would have the right to arrest the rig. ${ }^{52}$

A claim which gives rise to maritime lien status will survive a change in ownership of the rig, unless the change in ownership has been carried out through a Federal Court sale of the ship..$^{53}$ As a matter of practice, on the sale of a rig, it is prudent to obtain an indemnity in respect of any potential outstanding maritime lien claims. ${ }^{54}$ Maritime

The nature of a maritime lien is beyond the scope of this article. See W. Spicer, "Some Admiralty Law Issues in Offshore Oil \& Gas Development" (1982) 20 Alta. L. Rev. 153 at 161; The Sylph (1867), 2 L.R. 22 A. \& E. 24 [hereinafter The Sylph].

The Theta, [1894] P. 280. There is some doubt whether a person not onboard a ship who is injured as a result of the negligent navigation of a ship acquires a maritime lien. This issue was discussed in The Tolien, [1946] P. 135 and is further discussed in Thomas, Maritime Liens (Stephens, 1980) at 117 .

The Sylph, supra note 49; The Theta, ibid.

32 Certain types of maritime claims give rise to a right to arrest a vessel only if it can be established that the defendant would be liable in personam to the plaintiff. For instance, persons supplying "necessaries" to a ship have this status. This would include persons supplying fuel or any other services considered to be necessary for the operation of the ship. If the supplier is aware that it is providing its services to a charterer of the ship and not the owner, it will not have a right to arrest the ship for the outstanding claim. See, for instance, Feoso Oil Limited v. Sarla, [1995] 3 F.C. 68 (C.A.); Sabb Inc. v. Shipping Lid., [1976] 2 F.C. 175 (T.D.), affd (1979) I F.C. 461 (C.A.). W. Spicer, "Court Ordered Sale of Vessels" (1980) 11 J.M.L.A.C. 239; Thomas, supra note 50 at 297.

Part of the problem in ship sale transactions is that frequently the only asset of the selling company is the ship itself. In such circumstances, an indemnity is virtually worthless. If the purchaser has any real concems, the contract for the sale of the vessel should require the indemnity from a company which does have assets. 
liens are not required to be registered to be effective; ${ }^{55}$ therefore, only if an action has been commenced can one have any certainty as to the existence of a maritime lien.

\section{B. Salvage Services}

Any maritime property may be subjected to a claim for salvage. An oil rig would be considered maritime and subject to a claim for salvage in appropriate circumstances. ${ }^{\text {s6 }}$ Generally, claims for salvage may be brought where services are rendered to a vessel in danger where the service has resulted or contributed to relief from the danger. ${ }^{57}$ Finally, salvage claims give rise to a maritime lien and, accordingly, if a chartered vessel is salvaged, it may be arrested, notwithstanding that the owner may not be liable in personam.

Frequently, offshore supply vessels bringing goods and services to the offshore rig or standing by the rig as required are chartered by the oil company operator who has also chartered the oil rig. One frequently sees clauses in the supply vessel charter between the vessel owner and the oil company which provide that there should be no salvage award in respect of a salvaged vessel owned or operated by the supply vessel charterer (the oil company). The intention is to ensure that if the oil rig requires assistance which might be otherwise characterized as salvage, such a claim will not be made against the rig, or other supply vessels chartered by the oil company operator. Such clauses are problematic because the Canada Shipping Act renders invalid any clause in an agreement by which it is alleged that a seaman gives up his right to salvage. 58 This prohibition does not render such clauses invalid insofar as the Master is concerned, but there is nothing to prevent everyone else onboard a supply vessel from advancing a claim for salvage, notwithstanding a provision in the charter which attempts to prohibit such a claim.

\section{CHOICE OF LAW ISSUES}

With the realization that a drilling contract will be governed by maritime law, the preparation of such contracts should take into account some of the differences that exist between the maritime laws of different countries. In the context of the Canadian offshore, some of the differences between U.S. maritime law and that of Canada should be kept in mind.

Maritime liens arise in cases involving salvage, wages of crew members and damage caused by a ship (narrowly referred to as the collision lien, although it is in fact broader and encompasses any claim arising from damage done by a ship, for instance, damage caused by waves created by a ship).

so Particularly bearing in mind the comments of McLachlin J. in Bow Valley, supra note 1 at 418.

37 See W. Spicer, Canadian Maritime Law and the Ofshore: A Primer (Canadian Institute of Resources Law, 1984).

st Supra note $18, \mathrm{~s}$. 198. The only circumstance in which a seaman is entilled to give up his right to a claim for salvage is if he is employed on "salvage articles." This is intended to benefit the salvage tugs owned and operated by professional salvors which would not include the offshore supply vessel industry. 
Experience has shown that drilling contracts should be drafted in such a way as to point as strongly as possible in the direction of Canada. Although it is not possible to prevent an enterprising plaintiff from commencing a lawsuit in Texas, one can at least put up as many hurdles as possible. Some of those hurdles include:

(1) a Canadian substantive choice of law clause;

(2) an exclusive jurisdiction clause providing that disputes shall only be adjudicated before a specified court in a Canadian jurisdiction;

(3) if the parties wish to avoid litigation, a strong Canadian arbitration or mediation clause should be inserted; and

(4) reference in the contract to compliance with specified Canadian regulatory standards may be helpful.

It must be recognized, however, that while a Canadian court may well enforce the choice of law and jurisdiction agreement made between two sophisticated parties requiring litigation in Canada, it may be quite another matter if the potential plaintiffs are injured Canadian oil rig workers who have commenced a lawsuit in the United States. In Rowan Companies Inc. v. DiPersio,,$^{59}$ a Nova Scotia resident who had worked for Rowan Companies Inc. ("Rowan") in Canada and was covered by the Nova Scotia workers' compensation scheme was temporarily transferred to one of the Rowan rigs offshore Texas where he hurt his wrist. The plaintiff returned to Nova Scotia and claimed workers' compensation, but then brought an action in negligence against Rowan in Texas. The Appeal Division of the Nova Scotia Supreme Court refused to enjoin the plaintiff from proceeding with the action in Texas, even though he would have been prohibited from suing the company in Nova Scotia because of the prohibition against suit by a person covered by workers' compensation. In the result, the plaintiff continued to receive workers' compensation and the Texas lawsuit was settled for American dollars. 